\title{
NEUTUChAJÍCÍ SPOR O JiHOČÍNSKÉ MOŘE: STRATEGIE ZAJIŠŤOVÁNÍ JAKO VHODNÁ REAKCE STÁTŮ JIHOVÝCHODNÍ ASIE NA AKTIVITY Č́́NY V OBLASTI?*
}

Nikola Hájková **

\section{The Perpetual Dispute over the South China Sea: Hedging Strategy as a Suitable Reaction of Southeast Asian States to China's Activities in the Region?}

\begin{abstract}
This article deals with the perpetual territorial disputes in the South China Sea and attempts to explain the relations between China, the USA, the South China Sea states, and selected international organizations/regimes from the perspective of a hedging strategy. The hedging strategy is applied to the behaviour of South China Sea states in their efforts to face the constant rise of China's power as well as benefit from US presence and interests in this region. The goal of this study is to find out if the hedging strategy fits the behaviour of South China Sea states. The article is divided into four sections. In the first section, the concept of the hedging strategy is presented. The hedging strategy is comprised of three elements: engagement, soft balancing and enmeshing. The other sections of this article deal with these three elements in the region of the South China Sea. The initial idea is that the hedging strategy offers an alternative perspective on this challenge in the region compared to traditional international relations theories. On the other hand, the author admits that the concept of the hedging strategy has yet to be fully elaborated. This is why the main question remains unanswered. There is still much confusion regarding whether the hedging strategy is an appropriate strategy for states in the region.
\end{abstract}

Key words: territorial disputes, South China Sea, hedging, China, USA.

DOI: https://doi.org/10.24132/actaff.2018.10.1.3

${ }^{*}$ Text vznikl za podpory Institucionální podpory na dlouhodobý koncepční rozvoj výzkumné organizace 2018 Katedry politologie a mezinárodních vztahů FF ZČU v Plzni.

** Mgr. Nikola Hájková, Katedra politologie a mezinárodních vztahů, Fakulta filozofická, Západočeská univerzita v Plzni, nik.hajkova@gmail.com. 


\section{1. ÚVOD}

Již několik desetiletí vznášené nároky některých států východní a jihovýchodní Asie na skupinu ostrovů a ostrůvků v Jihočínském moři vytvářejí napětí mezi těmito zeměmi (jmenujme především Č́nskou lidovou republiku /dále jen Čínu/, Filipíny, Vietnam, Čínskou republiku /dále jen Tchaj-wan/, či Malajsii a Brunej). Své nároky státy opírají převážně o mezinárodní právo (zejména pak o UNCLOS), nicméně formulují i historické nároky (př́pad Č́ny). Nárůst teritoriálních požadavků je možné pozorovat hlavně po přijetí UNCLOS v souvislosti s definováním exkluzivní ekonomické zóny, nicméně zvýšená aktivita tamních zemí o prosazení svých nároků je v oblasti patrná zejména od roku 2015, kdy Č́na vydala novou Bílou knihu obrany, v níž deklaruje své záměry v Jihočínském moři (Ministry of National Defence. The People's Republic of China 2015). Spory panují o Spratlyho, Paracelské a Prataské ostrovy, o lavici Macclesfield a o mělčinu Scarborough. Jedním z důvodů, proč státy jeví o tyto oblasti zájem, je jejich strategický a ekonomický význam. ${ }^{1}$ Jedná se o křižovatky námořního obchodu, navíc bohaté na ryby a se značnými zásobami energetických surovin. ${ }^{2}$ Není proto divu, že se státy snaží prokázat, že jsou výše zmíněné ostrovy a mělčiny jejich teritoriem.

V současné době lze však v oblasti zaznamenat měnící se rovnováhu moci, jež vzbuzuje pozornost nejen tamních aktérů, ale i badatelů v oboru mezinárodních vztahů. Podstatou změny je mocenský vzestup Č́ny a její relativní posílení tváří v tvář USA, jež si snaží udržet své postavení v regionu jihovýchodní Asie. Čína patří mezi dominantní aktéry této oblasti a část Jihočínského moře považuje za svou exkluzivní ekonomickou zónu - vymezila ji tzv. devítibodovou linií, jež však zasahuje do exkluzivních ekonomických zón států oblasti tvořících prstenec kolem Jihočínského moře. Tyto státy pak hledají cestu, jak si zajistit své postavení v regionu. A jednou z cest, jak na čínský růst reagují, je i spolupráce s USA. Tradiční strategie jako vyvažování (balancing) a ustupování (appeasement) je v tomto kontextu těžké jednoznačně uplatnit. Na jedné straně státy nejen s Čínou, ale i mezi sebou, vedou teritoriální spory a pořádají společná vojenská cvičení $\mathrm{s}$ USA, ${ }^{3}$ na straně druhé spolu čile obchodují a spolupracují na půdě ASEAN. Kam toto chování zařadit? Zde se nabízí doposud nepř́liš rozvinutý koncept strategie tzv. zajištování (hedging), který navíc zahrnuje i vtahování (enmeshing) dalších aktérů.

Cílem tohoto textu je představit, jakým způsobem státy jihovýchodní Asie využívají ve své politice prvky tzv. strategie zajištování, a to konkrétně v reakci na aktivity Číny v oblasti Jihočínského moře. Časově je práce omezena na období po roce 2000, kdy dochází k nárůstu čínských nároků na teritoria v Jihočínském moři. Ve své současné Bílé knize obrany z roku 2017 pak Č́na klade důraz na ekonomiku, spolupráci a zaměření na Asii, přičemž pracuje s konceptem společné,

\footnotetext{
${ }^{1}$ Jihočínské moře má důležitý strategický a ekonomický význam (jen pro představu, oblast tvoří bránu mezi Indickým a Tichým oceánem a putuje tudy ročně více než 5 bilionů námořního obchodu (Cronin 2016) - vede tudy na $30 \%$ ze všech námořních tras světa (U. S. Department of Defense 2015: 5).

${ }^{2}$ Odhaduje se 11 miliard barelů ropy a 190 biliónů kubických metrů zásob zemního plynu (U. S. Department of Defense 2015: 5).

${ }^{3} \mathrm{~V}$ letošním roce došlo ke zrušení pozvání Číny na cvičení RIMPAC (The Rim of the Pacific Exercise) (Freiner 2018).
} 
komplexní, kooperativní a udržitelné bezpečnosti (Parameswaran 2017). Důležitým mezníkem je i rok 2011, kdy Obamova administrativa uvádí tzv. pivot do Asie, představovaný jako významný posun v zahraniční politice USA směrem od nákladných operací na Blízkém východě. I přesto však nelze tvrdit, že by pacifická oblast nebyla považována za důležitou i v předchozích administrativách (např. Bush jr. položil základy pro Trans Pacific Partnership /dále jen TPP/ či napomohl snížení napětí mezi Tchaj-wanem a Čínou) (Ford 2017). Ačkoliv z počátku panovalo z této strategie nadšení, nakonec se neukázala jako úspěšná. ${ }^{4}$ Se současným prezidentem Donaldem Trumpem pak došlo k okamžitému odstoupení od TPP.

V první části článku nejprve představím strategii zajištování, nastíním, v čem tato strategie spočívá, a vysvětlím, proč by mohla být vhodnou zahraničně-politickou strategií pro relativně menší a slabší státy (v porovnání s Čínou). V další části textu charakterizuji teritoriální spory v Jihočínském moři a představím, jak státy v okolí Jihočínského moře reagují na teritoriální nároky a zahraničně-politické aktivity Číny v této oblasti. Právě v této části poukáži na to, jak země využívají strategii zajištování. Tato strategie by měla dle Evelyn Goh (2005: viii) splňovat tři kritéria - angažování (engagement), nepřímé vyvažování ( soft balancing) a vtahování dalších aktérů (enmeshing). V následujícím textu se pokusím ukázat, jak jsou jednotlivé části strategie naplňovány v zahraniční politice vybraných zemí jihovýchodní Asie, a to jak v oblasti vojenské, tak i ekonomické a geopolitické.

\section{Strategie zajišǐování - ReAkCe na Čínské snahy o hegemoniı V OBLASTI JIHOČÍNSKÉHO MOŘE?}

Jak již bylo řečeno v úvodu, společně s mocenským vzestupem Číny a jejími ambicemi v Jihočínském moři vyvstává otázka, jak reagují a budou reagovat ostatní pobřežní státy. Není nepochopitelné, že se blízkých teritorií nechtějí vzdát, respektive že chtějí těžit z jejich strategické pozice a bohatství. Otázkou však je, jakou cestou toho dosáhnout. Samotné státy se svou velikostí a mocí mohou jen těžko rovnat státu, jakým je Čína. V současné době v regionu jihovýchodní Asie není stát, který by bylo možné označit za protiváhu Č́ně. USA se v regionu angažují a jejich aktivity je možné chápat jako vyvažování Č́ny, nicméně jde o mimoregionální mocnost a navíc se nezdráhají s Čínou v mnoha ohledech spolupracovat (jmenujme např. Asijsko-pacifické hospodářské společenství, dále jen APEC).

Jak se tedy mají zachovat státy oblasti Jihočínského moře? Zde se otevírá prostor pro strategii zajištování. Přikloněním se bud' jen k Číně, nebo jen k USA by mohlo v budoucnu znamenat rozdělení regionu na dva soupeřící bloky. Ačkoliv USA s Č́nou soupeří o strategické postavení v regionu, na druhou stranu jsou obě tyto ekonomiky v rámci globalizovaného světa propojené a navazují bilaterální obchodní vazby. Pro menší státy oblasti Jihočínského moře je tedy výhodnější se nevymezovat ani vưči Číně, ani vưči USA a naopak těžit z výhod spolupráce, která se nabízí, a navíc se pokusit vtáhnout i další aktéry, jež mají v regionu také své zájmy (např. Austrálie a iniciace APEC, dále jmenujme Japonsko či Korejskou republiku).

\footnotetext{
${ }^{4}$ Jmenujme např. selhání TPP či oslabení vztahů s Filipínami po zvolení prezidenta Duterteho, jehož boj proti drogám byl (nejen) ze strany USA kritizován (Brooks 2016).
} 
Samotná strategie zajištování pochází z ekonomie. Jedná se o strategii, v níž se daný aktér snaží vytvořit si takovou pozici na trhu, aby se co nejvíce vyvaroval budoucích rizik (příkladem může být zahraniční obchod, v němž se aktéři snaží např. snížit riziko pohybu kurzu měn, v nichž obchodují). V mezinárodních vztazích se zatím jedná o nepř́lišs rozvinutý koncept, avšak hlavní rys zůstává stejný - snaha o vyvarování se budoucímu riziku. Nepanuje však shoda na tom, jaké konkrétní charakteristiky poměru sil by měl stát využívající strategii zajištování splňovat, a dokonce ani na tom, jak by vyvarování se riziku mělo vypadat, či lépe řečeno, jaké kroky by měly být považovány za kroky směřující k zajištování a jaké už ne. Dle Hlaváčka (2016: 55-57) se autoři neshodují ani na tom, pro jaké státy je tato strategie typická - zda je to strategie vhodná výslovně pro malé státy, či naopak pro velmoci.

Mluvíme-li o čínském růstu, je nutné zmínit, že i toto je oblast, v níž se autoři rozcházejí. Jedna skupina (např. Goh 2005; Kuik 2016) tvrdí, že pojímáním strategie zajištování jako reakce na čínský růst činíme z této strategie specifickou formu vyvažování, druhá skupina (např. Kang 2003) naopak zastává názor, že zajištování je svébytnou strategií, která vznikla v reakci na čínský růst. Tím se dostáváme k možnostem aplikování této strategie. V současné době se v souvislosti se strategií zajištování hovoří převážně o chování menších států v oblasti Jihočínského moře, ačkoliv jsou i autoři, kteří tvrdí, že tato strategie je obecně uplatnitelná na jakéhokoliv aktéra mezinárodních vztahů, protože každý aktér se snaží co nejvíce rozptýlit potencionální rizika (Tessman, Wolfe 2011 dle Hlaváček 2015: 55-57).

Evelyn Goh (2005: viii) stanovuje tři základní charakteristiky strategie zajištování. V první řadě by měl zajištujující se stát (hedger) vést politiku angažovanosti. Jejím cílem má být vytvoření úzkých ekonomických, politických a vojenských vztahů se státem, vůči němuž je strategie namírena. Na druhou stranu by pak měl tento stát, s nímž vede politiku angažovanosti, i nepřímo vyvažovat pomocí posilování svých vojenských kapacit a diplomatických aktivit, a to takovým způsobem, aby nebyly namířeny proti žádné konkrétní zemi. V neposlední řadě by pak měl zajištující stát vtahovat jiné aktéry regionu s cílem vytvořit stabilní regionální řád.

Podle Evelyn Goh (2005: viii) je zajištování takovou strategií, při níž se státy vyhýbají situacím, ve kterých by se musely rozhodnout pro některou z tradičních strategií - vyvažování, ustupování či neutralitu. Na místo toho se snaží udržet si pozici „na střední cestě“ a nemusí si tak vybírat, k jaké straně se přiklonit a při tom těžit výhody z navazování vzájemných vztahů, a to pomocí již výše zmíněného - angažování se, nepřímého vyvažování a vtahování dalších aktérů.

$\mathrm{Na}$ případ teritoriálních sporů v oblasti Jihočínského moře pak lze strategii zajištování aplikovat následujícím zpo̊sobem: menší státy by měly vést politiku angažovanosti vůči Č́ně s cílem její socializace v mezinárodních vztazích (myšleno jako přijetí zavedených norem jednání v mezinárodním prostředí) a zamezit tak potencionální čínské agresi. Dále by se měly snažit Čínu nepřímo vyvažovat skrze spolupráci s USA, aby bylo zajištěno, že se USA z regionu nestáhnou. V neposlední řadě by měly vtahovat silné aktéry regionu, aby byla zajištěna jeho stabilita. V důsledku je tedy cílem států oblasti Jihočínského moře zamezit čínské hege- 
monii a stažení USA z této oblasti a udržet tak regionální řád stabilní s tím, že se neomezí jen na tyto dva vlivné aktéry, nýbrž svou strategii postaví i na spolupráci s dalšími, méně vlivnými aktéry uvnitř regionu i mimo něj (Goh 2005: viii). Zjednodušeně je pak definice strategie zajištování shrnuta v tabulce 1.

Tabulka 1: Využití strategie zajištování jako rámce pro analýzu mezistátních vztahů $v$ oblasti Jihočínského moře

\begin{tabular}{|l|l|l|}
\hline Co dělat? & S kým? & Za jakým účelem? \\
\hline \hline Angažovat se & s Čínou & $\begin{array}{l}\text { socializovat Čínu, aby přijala modely jednání } \\
\text { v mezinárodních vztazích }\end{array}$ \\
\hline Nepř́mo vyvažovat & s USA & ujistit se, že se USA neuchýlí do izolace \\
\hline Vtahovat & s vlivnými aktéry regionu & vytvořit stabilní regionální řád \\
\hline
\end{tabular}

Zdroj: Goh (2005), upraveno v Hlaváček (2016: 58)

Strategie zajištování je způsobem, jak pragmaticky reagovat na strukturální změny regionálního řádu v oblasti Jihočínského moře. S růstem čínské moci a společně s ambicemi Č́ny stát se námořní mocností (nejen pozemní, jíž byla doposud) (Ministry of National Defence. The People's Republic of China 2015) by se mohla změnit rovnováha moci ve prospěch Číny. Státy jihovýchodní Asie nechtějí ustupovat čínským ambicím, ale na druhou stranu ani nechtějí přímo vyvažovat Čínu spoluprací s USA. Na následujících řádcích se pokusím ukázat využití strategie zajištování v politikách zemí jihovýchodní Asie, kterých se týkají teritoriální spory v Jihočínském moři. Nejprve se zaměřím na politiku angažovanosti s Čínou, poté na nepřímé vyvažování Číny spoluprací s USA a v neposlední řadě na vtahování ostatních aktérů.

\section{TERITORIÁLNí SPORY V JiHOČíNSKÉM MOŘI}

V této části textu se budu zabývat konkrétními aktivitami Číny a zainteresovaných států jihovýchodní Asie, jež podnikají pro naplnění a utvrzení svých nároků v Jihočínském moři. Začnu aktivitami Číny, která svůj nárok na celou oblast Jihočínského moře deklaruje již od skončení druhé světové války, a následně se zaměřím na politiky menších států oblasti, které se proti čínským snahám snaží vymezit. Teritoriální spory v Jihočínském moři, resp. čínské nároky na tuto oblast, bývají považovány za stěžejní mezník ve vývoji vztahů mezi Čínou a menšími státy regionu. Ačkoliv si Čína nárokuje celou oblast Jihočínského moře, ostatním přímořským státům se poměrně daří udržet si území, na něž vznášejí nároky a jež považují za své (alespoň tedy část z nich ${ }^{5}$ ). Avšak kromě toho, že jsou tyto teritoriální spory určující pro bilaterální vztahy mezi státy v okolí Jihočínského moře, odráží se i na multilaterální úrovni (viz snahu zemí řešit teritoriální spory na půdě ASEAN) a ve vztazích se státy mimo region (snaha zapojit do řešení problémů USA a vtáhnout do nich např̀. Japonsko či Austrálii díky multilaterálním dohodám - viz níže).

\footnotetext{
${ }^{5}$ Čína, Vietnam a Tchaj-wan si např. nárokují všechny Paracelské a Spratlyho ostrovy, reálně však ovládají jen některé z nich (viz tabulku 2).
} 
Proč se státy zajímají o ostrovy a mělčiny v Jihočínském moři? Od roku 2015, kdy Čína zveřejnila novou Bílou knihu obrany, kde deklaruje své záměry v Jihočínském moři, oproti předchozím létům výrazně narostly u ostatních států oblasti snahy o zajištění si svých teritoriálních nároků. Pomocí strategie zajištování by se státům podařilo pojistit si své postavení v regionu vůči snaze Číny o hegemonii v oblasti. Kromě toho přidávají zásoby ropy a zemního plynu, které se kolem nich skrývají a z nichž by státy mohly čerpat, ostrovům na atraktivnosti a došlo by tak k upevnění a/nebo rozšíření jejich exkluzivních ekonomických zón (byt to je sporné, protože většina z útvarů není dle mezinárodního mořského práva uznávána za ostrovy, na něž lze uplatňovat svou suverenitu - většina z nich se např̀ při př́livu nachází pod hladinou /UN 1982: 66/). Jako symbol suverenity nad danými útvary na nich státy budují různé stavby - typicky vojenské základny, ale např. i majáky. Č́na pak některé z nárokovaných ostrovů uměle dobudovává (viz níže).

Nejvíce nároků ze všech zemí oblasti vznáší bezesporu Čína. Ta již po druhé světové válce vytyčila hranici svých teritoriálních vod, v současné době známou jako tzv. devítibodová linie. Čína si nárokuje celou oblast Jihočínského moře a kromě výše zmíněných ostrovů zasahuje i do exkluzivních ekonomických zón přilehlých států. Č́nský zájem o tuto oblast je spjat zejména s jejím cílem neustálého ekonomického růstu, k jehož naplnění by ji kromě jiného mělo napomoci zajistit si stálý přístup k energetickým zdrojům. A těch je v Jihočínském moři poměrně dost. ${ }^{6}$ Od roku 2013 začíná být Čína velmi aktivní v podpoře svých nároků - kromě stavby, rozšiřování a zdokonalování základen ostrovy uměle dotváří a zpevňuje (U. S. Department of Defense 2015: 15). Ačkoliv si nárokuje celou oblast Jihočínského moře, reálně např. spravuje ze Spratleyho ostrovů pouze sedm útvarů. Většinu z nich spravuje od roku 1988, jeden (Mischief Reef) pak od roku 1995 (Vuving 2016). I přes její rétoriku o mírovém řešení teritoriálních sporů a $\mathrm{v}$ souvislosti $\mathrm{s}$ Bílou knihou obrany z roku 2017 představením bezpečnosti jako komplexní, společné, kooperativní a udržitelné (Parameswaran 2017) i nadále pokračuje v budování vojenských základen na jimi spravovaných ostrovech a vytváří si tak v oblasti strategické pozice. Vojenské základny jsou neustále vylepšovány, budují se komunikace a do provozu jsou uváděny radary (AMTI 2017). Čína tak neustále navyšuje svoji schopnost efektivně operovat $\mathrm{v}$ Jihočínském moři.

Své nároky se snaží prosazovat i na multilaterální úrovni - vznesla dvě verbální nóty ke generálnímu tajemníkovi OSN, v níž si nárokuje přibližně dva miliony kilometrů čtverečních námořního prostoru v Jihočínském moři společně s tvrzením, že má nad ostrovy v této oblasti nespornou svrchovanost a tím pádem i nad okolními vodami a mořským dnem (U. S. Department of Defense 2015: 8).

Druhým největším nárokovatelem je hned po Číně Vietnam. Ten také usiluje o kontrolu nad všemi Paracelskými a Spratlyho ostrovy. Na šesti z jeho základen vybudoval heliporty a mimo jiné zdokonaloval své další základny (U. S. Department of Defense 2015: 15). Avšak čínskému tempu nestačí. Dalším státem, který vznáší nároky na teritoria v Jihočínském moři, jsou Filipíny. Ty např. v 80. letech vybudovaly na Thitu Reef letiště (U. S. Department of Defense 2015: 15). Mezi další státy, jež si v Jihočínském moři nárokují nějaké území, patří i Malajsie, která

\footnotetext{
${ }^{6}$ Kromě již výše zmíněných zásob ropy a zemního plynu jde také o bohatou rybolovnou oblast.
} 
kupř. vybudovala letiště na Swallow Reef. Malajsie však není př́liš aktivní a na některých z ostrovů přerušila svou přítomnost a mimo jiné se pokouší čínské aktivity přehlížet (Hlaváček 2016: 67).

Opomíjeným, resp. ne příliš zmiňovaným státem, který je také účastníkem teritoriálních sporů v oblasti Jihočínského moře, je Brunej. Nárokuje si dva ostrovy, přičemž reálně ovládá jeden z nich - Louisa Reef. Své nároky začal prosazovat po získání nezávislosti v roce 1984 v souvislosti s požadavkem na kontrolu exkluzivní ekonomické zóny. Jako jediný z doposud jmenovaných států v oblasti není na žádném ostrově vojensky přítomný (Vuving 2016). Ostrov využívá k těžbě ropy.

V oblasti vznáší požadavky ještě Indonésie, ta si však nenárokuje žádný pevninský útvar, nýbrž „pouze“ exkluzivní ekonomickou zónu (U. S. Department of Defense 2015: 7). V otázce teritoriálních nároků však nelze opomenout Tchaj-wan. Ačkoliv se dle mezinárodních standardů nejedná o stát, protože splňuje jen některé prvky státnosti (nedisponuje vnější suverenitou), v Jihočínském moři vznáší teritoriální nároky na všechna území Spratlyho a Paracelských ostrovů (U. S. Department of Defense 2015: 7), ovšem ve skutečnosti spravuje jen jeden ostrov, a to ostrov Itu Aba, který je však ze Spratlyho ostrovů největší. Diskutabilní je pak jeho správa Ban Than Reef, kde v roce 1994 a poté v roce 2004 započal stavební práce, přičemž sem jeho představitelé a akademičtí pracovníci podnikli oficiální cesty (Vuving 2016; Ministry of Foreign Affairs Republic of China (Taiwan) 2016). Nicméně od roku 2013 začíná být Tchaj-wan velmi aktivní na ostrově Itu Aba započal zde čilé stavební práce a instaluje zde solární pole (U. S. Department of Defense 2015: 15). Nelze opomenout ani jeho snahy o uznání Itu Aby za ostrov dle mezinárodního mořského práva. Tento pokus byl však mezinárodním rozhodčím tribunálem zamítnut (Myers 2018).

V následující tabulce (tab. 2) se pokouším shrnout, jaké státy regionu ovládají která území v Jihočínském moři. Každý stát uvádí odlišné hodnoty v počtu nárokovaných útvarů - důvodem je, že každý stát má jiná kritéria, která se liší dle toho, co považuje za „osídlený útvar" a co nikoliv (některé státy považují za osídlení třeba i maják, některé základnu apod.) a navíc se některé útvary skládají z několika menších a v tomto případě některé země počítají daný útvar jako jeden celek, některé zahrnují do počtu každou jeho část zvlášt. Některé státy počítají jen ty ostrovy, co jsou při př́livu nad hladinou, jiné i ty, co jsou pod hladinou. $\mathrm{V}$ této tabulce se snažím sloučit jednotlivé př́ístupy a získat tak co největší přehled o územích v Jihočínském moři, jež jsou jednotlivými státy nárokována. Z toho důvodu jsou některé útvary uvedené v tabulce vícekrát - na budování „osídlení“ na ostrově se podílelo více států a nyní je jejich status sporný. 
Tabulka 2: Jihočínské moře - nárokovaná územī

\begin{tabular}{|c|c|c|c|}
\hline & Spratlyho ostrovy & Paracelské ostrovy & Další \\
\hline Čína & $\begin{array}{l}\text { Subi Reef, Gaven Reefs, } \\
\text { Hughes Reef, Johnson } \\
\text { Reef, Mischief Reef, } \\
\text { Fiery Cross Reef, } \\
\text { Cuarteron Reef,Second } \\
\text { Thomas Shoal, South } \\
\text { Luconia Shoal }\end{array}$ & $\begin{array}{l}\text { Woody Island, Lincoln } \\
\text { Island, Pyramid Rock, } \\
\text { Rocky Island, Passu } \\
\text { Keah, Triton Island, } \\
\text { Crescent Group a další }\end{array}$ & $\begin{array}{l}\text { Scarborough Shoal, } \\
\text { Prataské ostrovy, } \\
\text { Macclesfield Bank }\end{array}$ \\
\hline Malajsie & $\begin{array}{l}\text { Swallow Reef, Ardasier } \\
\text { Banks, Mariveles Reef, } \\
\text { Erica Reef, Investigator } \\
\text { Shoal }\end{array}$ & & \\
\hline Filipíny & $\begin{array}{l}\text { Commodore Reef, } \\
\text { Nanshan Island, Flat } \\
\text { Island, West York } \\
\text { Island, North Danger } \\
\text { Reef, Thitu Reefs, } \\
\text { Loaita Islands, Second } \\
\text { Thomas Shoal }\end{array}$ & & $\begin{array}{l}\text { Scarborough Shoal, } \\
\text { Macclesfield Bank }\end{array}$ \\
\hline Vietnam & $\begin{array}{l}\text { Vanguard Bank, Prince } \\
\text { Consort Bank, Grainger } \\
\text { Bank, Alexandra Bank, } \\
\text { Prince of Wales Bank, } \\
\text { Ladd Reef, Spratly } \\
\text { Island, Rifleman Bank, } \\
\text { London Reefs, Amboyna } \\
\text { Cay, Barque Canada } \\
\text { Reef, Pearson Reef, } \\
\text { Alison Reef, Cornwaillis } \\
\text { Reef, Tennent Reef, } \\
\text { Collins Reef, Sin Cowe } \\
\text { Island, Lansdowne } \\
\text { Island, Grierson Reef, } \\
\text { Discovery Great Reef, } \\
\text { Namyit Island, Sand } \\
\text { Cay, Petley Reef, North } \\
\text { Danger Reef, Bombaj } \\
\text { Castle }\end{array}$ & & \\
\hline Brunej & $\begin{array}{l}\text { Louisa Reef, Bombay } \\
\text { Castle }\end{array}$ & & \\
\hline Tchaj-wan & $\begin{array}{l}\text { Itu Aba Island, Ban } \\
\text { Than Reef }\end{array}$ & & $\begin{array}{l}\text { Scarborough Shoal, } \\
\text { Prataské ostrovy, } \\
\text { Macclesfield Bank } \\
\end{array}$ \\
\hline
\end{tabular}

Zdroj: autorka dle U. S. Department of Defense (2015), CIA (2018) a Vuving (2016)

Kromě snah o kultivaci ostrovů se státy snaží své nároky bránit a utvrzovat i jinými cestami. Bilaterálně se jedná o nežádoucí vymáhání silou. Mezi nejvážnější střety řadí BBC (2016: nestr.) ty, které proběhly mezi Čínou a Vietnamem, a to konkrétně střet z roku 1974, kdy došlo k obsazení Paracelských ostrovů Cínou,

\footnotetext{
${ }^{7}$ Čína, Tchaj-wan a Vietnam si nárokují všechny z Paracelských a Spratlyho ostrovů. Zde jsou vypsány ty z nich, na kterých mají reálně nějaké osídlení či je nějakým zpưsobem spravují. Proto nejsou u těchto států vypisovány všechny ostrovy ze souostroví. Dále se některé ostrůvky nacházejí v tabulce u více států. Je tomu tak proto, že u nich nelze jednoznačně určit, který stát jej spravuje, anebo byly v nedávné minulosti spravovány jiným státem.
} 
nebo z roku 2014, kdy Čína oznámila, že chce poblíž Paracelských ostrovů umístit ropnou plošinu. Dále často probíhají střety mezi Čínou a Filipínami. Na druhou stranu se státy snaží řešit problémy i mírovými prostředky. Obecně vzato jsou stabilizačním faktorem ekonomické vazby - např. snaha Číny o navázání dobrých ekonomických vztahů skrze iniciativu námořní hedvábné stezky či konkrétněji kupř́ḱladu s Vietnamem skrze Smlouvu o delimitaci teritoriálních moří, exkluzivní ekonomické zóny a kontinentálního šelfu v Tonkinském zálivu z roku $2000 .{ }^{8} \mathrm{Na}$ multilaterální úrovni se pak státy oblasti Jihočínského moře snaží problematiku prosazovat na půdě ASEAN či pomocí soudních sporů (nap̌r. Filipíny zažalovaly Čínu u Mezinárodního soudního dvora v Haagu, viz níže).

Je patrné, že menší státy v okolí Jihočínského moře volí celou škálu prostředků v reakci na stupňující se aktivity Číny v této oblasti. Ačkoliv nelze popřít, že teritoriální spory nejsou vedeny jen mezi zainteresovanými státy jihovýchodní Asie a Čínou, ale i mezi těmito státy navzájem (příkladem budiž třeba spor Malajsie a Bruneje o Louisa Reef) (Vuving 2016), na významu nabývají právě spory s Čínou. Čína zažívá nebývalý ekonomický růst a spolu s modernizací jejího námořnictva dochází k posilování její pozice mimo jiné právě i v oblasti Jihočínského moře. Po zveřejnění její poslední Bílé knihy obrany v roce 2015 se navíc ukazuje, že Čína se již necítí být jen tradičně pozemní mocností, ale svou pozornost obrací na moře. Obrat na moře je viditelný zejména ve dvou směrech - za prvé, Čína deklaruje své záměry a nároky na teritoria v Jihočínském moři a, za druhé, je kladen důraz na modernizaci válečného námořnictva (Hlaváček 2016: 54). ${ }^{9}$ Menší státy se s touto změnou v kurzu zahraniční politiky musí vyrovnat a nějak jí čelit. Otázkou však je, jakou strategii zvolí. Na jedné straně se musí vypořádat s čínskou agresí v Jihočínském moři, na straně druhé s Čínou spolupracují v ekonomickém sektoru a zapojují ji do regionálních multilaterálních organizací (typickým př́kladem je ASEAN+3 či ASEAN+1). Pak ale participují i na vojenských cvičeních s USA. Jaká strategie se zde nabízí? V dalších částech textu ukážeme, jak země využívají strategii tzv. zajištování, o které se v souvislosti s měnící se rovnováhou moci v Asii a Pacifiku v posledních letech hovoří.

\subsection{Politika angažovanosti s Čínou}

Zvýšení čínské pozornosti vůči oblasti Jihočínského moře lze zaznamenat zejména v období po druhé světové válce v souvislosti s vymezením tzv. devítibodové linie. Tzv. devítibodová linie je linií, jíž Čína vymezila své teritoriální nároky v Jihočínském moři. Samotná linie prošla postupným vývojem. První body se na mapě zveřejněné Čínou objevily v roce 1947. Linie zahrnuje prakticky celou oblast Jihočínského moře a zasahuje do exkluzivních ekonomických zón přilehlých států. Mimo jiné zahrnuje i Paracelské, Spratlyho a Prataské ostrovy, lavici Macclesfieldovu a Scarboroughovu mělčinu, jež jsou rovněž nárokovány přilehlými státy.

\footnotetext{
${ }^{8} \mathrm{O}$ využití poledníku jako hranice viz Dohodu mezi Čínskou lidovou republikou a Vietnamskou socialistickou republikou o vymezení územních moří, výlučných hospodářských zón a kontinentálních šelfů obou zemí v zálivu Beibu / zálivu Bac Bo (CIL NUS 2000).

${ }^{9} \mathrm{I}$ když nelze popřít, že by $\mathrm{k}$ modernizaci nedocházelo již dříve - zmiňme např. nákup letadlové lodě Liaoning v roce 1998 (The Guardian 2011).
} 
Čínský zájem o oblast Jihočínského moře je spjat zejména s čínskou honbou za ekonomickým růstem a se snahou zajistit si př́istup ke zdrojům, z nichž jmenujme hlavně ropu a zemní plyn, jejichž naleziště se nacházejí právě v oblasti výše zmiňovaných ostrovů a ostrůvků. Č́na své nároky na tuto oblast ospravedlňuje zvykovým právem objevu a historickým právem jejich osvobození od nadvlády Japonců. Navíc to podle čínského tvrzení neodporuje UNCLOS. Představitelé Číny mimo jiné tvrdí, že celá oblast Jihočínského moře je součástí jejího kontinentálního šelfu (Gao, Bing 2013: passim). To však vyvrátil Mezinárodní soudní dvůr v Haagu v červnu 2016 (Hunt 2016).

Vztahy Číny a států jihovýchodní Asie v okolí Jihočínského moře jsou poznamenány čínskými teritoriálními nároky v tomto moři, nicméně existují zde jisté stabilizační faktory - a to zejména v podobě ekonomické a politické spolupráce. $\mathrm{V}$ řádcích níže se zaměřím na to, jak se státy sousedící s Jihočínským mořem snaží angažovat s Čínou ve vojenském, ekonomickém a politickém sektoru. Základní rysy politiky angažovanosti s Č́nou jsou shrnuty v tabulce 3.

Vojenský sektor. Spolupráce států oblasti Jihočínského moře s Čínou ve vojenském sektoru není na rozdíl od té s USA (viz níže) natolik rozvinutá. Nicméně Čína má od roku 2013 navázáno strategické partnerství s Malajsií, s níž v roce 2014 uskutečnila první společné vojenské cvičení, následně bylo opakováno v roce 2015 i v roce 2016 (Parameswaran 2014). Kromě toho země podepsaly v roce 2005 memorandum o porozumění týkající se spolupráce v obraně. Společná vojenská cvičení nesou název Mír a přátelství (Parameswaran 2014). Dále má Čína navázáno strategické partnerství s Vietnamem, avšak došlo mezi nimi již k několika střetům kvůli teritoriálním nárokům v Jihočínském moři. Přelom nastal ve vztazích s Filipínami - v roce 2017 se nechal filipínský prezident Duterte podle ABS CBN (2017) slyšet, že je otevřený ke společnému vojenskému cvičení s Čínou, které by se mohlo konat ve filipínských vodách. S dalšími státy v oblasti Čína nepodniká žádnou spolupráci ve vojenském sektoru. Výjimku tvoří Cvičení pacifického pobřeží (The Rim of the Pacific Exercise, dále jen RIMPAC) - společné vojenské cvičení států Pacifiku, které je největším společným vojenským cvičením na světě (viz níže), nicméně jak již bylo zmíněno výše, její pozvání na toto cvičení pro rok 2018 bylo Donaldem Trumpem odvoláno.

Ekonomický sektor. V oblasti ekonomických vztahů by se mohla jevit jako významný stabilizační faktor iniciativa Číny na vybudování námořní hedvábné stezky. Ta vychází ze skutečnosti, že se Čína stává námořní mocností a snaží se využít strategického potenciálu Jihočínského moře. Pro státy v jeho okolí se tak naskýtá možnost nejen ke stabilizaci vztahů s Čínou, ale i k transformaci průmyslu (Lu 2016: 376). Iniciativa k vybudování námořní hedvábné stezky spočívá v navázání a posílení vztahů se státy napříč oblastí přiléhající k Jihočínskému moři, a tím vytvoření obchodních tras, které budou směřovat do Indického oceánu. Obchodní koridory vytvořené $\mathrm{v}$ rámci námořní hedvábné stezky by měly zahrnovat různé sektory ekonomiky - od zemědělství po turismus. Jedním z již budovaných ekonomických koridorů v Jihočínském moři je Brunej-Guangxi koridor, jehož hlavním cílem je rozvinout obchodní výměnu bio produktů, které odpovídají standardům halal (SQW 2014). 
Mezi významné investiční země, kam míři investice z Číny, patří Filipíny a Malajsie. Obchodní výměna mezi nimi a Čínou od roku 2000 postupně narůstá. ${ }^{10}$ Ačkoliv jsou čínsko-filipínské vztahy poznamenány incidenty v Jihočínském moři, stal se z Číny významný obchodní partner. Za formální stvrzení čínsko-filipínských vztahů pak můžeme považovat Společné prohlášení mezi Čínou a Filipínami z roku 2000 (Devadason 2016: 48). Co se týče Vietnamu, je jeho ekonomický vztah s Čínou narušen tím, že svůj ekonomický růst postavil na levné pracovní síle. Byt vzájemná obchodní výměna neustále roste, těží z ní výhody spíše Čína než Vietnam (Hlaváček 2016: 64).

V rámci platformy Komplexního regionálního partnerství ASEAN (Regional Comprehensive Economic Partnerhip, dále jen ASEAN RCEP) mají země ASEAN možnost rozvíjet ekonomické vztahy s Čínou, Japonskem, Jižní Koreou, Indií, Austrálií a Novým Zélandem. Vytvoření zóny volného obchodu je dalším stabilizačním faktorem v regionu, na kterém participují i země ležící mimo region. Program byl vytvořen v reakci na (viz níže) (ASEAN 2016a).

Již několikrát bylo zmíněno, že oblast Jihočínského moře je bohatá na ropu a zemní plyn. Vzhledem k tomu, že podle čínské strategie Going global (Eichler 2013: 232) je k udržení ekonomického růstu důležité zajistit si př́ístup ke zdrojům, pak se nabízí, že vhodným zpo̊sobem zajištění dostatečných energetických zdrojů je navazování ekonomických vazeb se státy, které těmito zdroji disponují. V tomto kontextu by bylo záhodno zmínit Brunej, jež s Čínou navazuje čilé ekonomické styky založené na obchodu s ropou (mezi China National Offshore Oil Corporation a Brunei National Petroleum Company Sendirian Berhad) (CNOOC 2013).

Politický sektor. V rámci politického sektoru jsou důležitým stabilizačním faktorem ve vztazích s Čínou regionální organizace a režimy, jako je např. ASEAN+1, ASEAN+3 či APEC. Tyto instituce jsou aktivní v nastolování témat a kromě jiného slouží jako diskuzní platforma. Jedním z př́íkladů posilování vztahů mezi zeměmi ASEAN, do kterých se zapojila mimo jiné právě i Čína, je Dohoda o přátelství a spolupráci zemí (ASEAN Treaty of Amity and Cooperation), jejímž cílem je posilovat regionální mír a stabilitu (ASEAN 2016b). Nelze opomenout ani APEC patřící mezi důležité platformy v regionu (Clinton 2011: 61).

Co se týče bilaterálních vztahů, první zemí, která vůči Číně začala vést politiku angažovanosti, byla Malajsie (v roce 1974), byt byla Čína před koncem studené války brána jako bezpečnostní hrozba. Malajsie v současné době zastává pročínský postoj - zejména to lze pozorovat právě v souvislosti s teritoriálními nároky v Jihočínském moři (Malajsie se k čínským aktivitám nevyjadřuje) (Hlaváček 2016: $62)$.

Vztahy s Vietnamem jsou poznamenány jeho nedůvěrou vůči Číně, avšak důležitým faktorem ve vzájemných vztazích je charakter politického režimu - obě země jsou komunistické, a proto je pro Vietnam strategické udržovat s Č́nou seriózní vztahy už ,jen“ kvůli zachování vlastního režimu (Hlaváček 2016: 64). Od vzájemného narovnání vztahů v roce 1991 je vztah Číny a Vietnamu založen na rozšiřování spolupráce (Do 2017), která se skládá ze tří úrovní: spolupráce mezi vládami, spolupráce mezi politickými strany (roz. komunistickými) a spoluprací mezi

\footnotetext{
48).

${ }^{10}$ Významný nárůst obchodních vztahů po roce 2000 zejména s Malajsií (Devadason 2016:
} 
lidmi (Strašáková 2017: 6). Nicméně nelze opomenout, že vzájemné vztahy jsou poznamenány teritoriálními spory v Jihočínském moři, které jsou blíže popsány výše.

Tabulka 3: Angažování s Č́nou ${ }^{11}$

\begin{tabular}{|c|c|c|c|c|c|}
\hline & \multicolumn{2}{|c|}{ Vojenský } & Politický & \multicolumn{2}{|c|}{ Ekonomický } \\
\hline Vietnam & $\begin{array}{l}\text { Bez společných } \\
\text { vojenských } \\
\text { cvičení, vztahy } \\
\text { poznamenány } \\
\text { střety } \\
\text { v Jihočínském } \\
\text { moři }\end{array}$ & \multirow{4}{*}{ RIMPAC } & \begin{tabular}{|l|} 
Náklonnost \\
z důvodu \\
komunistických \\
režimů, nicméně \\
vztahy narušeny \\
incidenty \\
v Jihočínském \\
moři
\end{tabular} & $\begin{array}{l}\text { Konkurenční } \\
\text { vztah, byt } \\
\text { obchodní } \\
\text { výměna roste }\end{array}$ & \multirow{4}{*}{$\begin{array}{l}\text { Iniciativa } \\
\text { námořní } \\
\text { hedvábné } \\
\text { stezky, RCEP }\end{array}$} \\
\hline Malajsie & $\begin{array}{l}\text { Společná } \\
\text { vojenská cvičení } \\
\text { od roku 2015, } \\
\text { status } \\
\text { strategického } \\
\text { partnerství }\end{array}$ & & $\begin{array}{l}\text { Pročínský } \\
\text { postoj, } \\
\text { přehlížení } \\
\text { čínských aktivit } \\
\text { v Jihočínském } \\
\text { moři }\end{array}$ & $\begin{array}{l}\text { Významný } \\
\text { nárůst po roce } \\
2000\end{array}$ & \\
\hline Brunej & & & $\begin{array}{l}\text { Pročínský } \\
\text { postoj, snaha } \\
\text { řešit teritoriální } \\
\text { nároky } \\
\text { v Jihočínském } \\
\text { moři mírovou } \\
\text { cestou }\end{array}$ & $\begin{array}{l}\text { Brunej-Guangxi } \\
\text { koridor, čínská } \\
\text { závislost na } \\
\text { brunejských } \\
\text { zásobách ropy }\end{array}$ & \\
\hline Filipíny & $\begin{array}{l}\text { Ochota ke } \\
\text { společným } \\
\text { vojenským } \\
\text { cvičením }\end{array}$ & & \begin{tabular}{|l|} 
Vztahy \\
poznamenány \\
vzájemnou \\
nedůvěrou, \\
arbitáž vůči Číně
\end{tabular} & $\begin{array}{l}\text { Č́na } \\
\text { významným } \\
\text { obchodním } \\
\text { partnerem }\end{array}$ & \\
\hline \multirow[t]{2}{*}{ Tchaj-wan } & $\begin{array}{l}\text { Vzájemná } \\
\text { nedůvěra }\end{array}$ & - & $\begin{array}{l}\text { Čína považuje } \\
\text { Tchaj-wan za } \\
\text { separatisty, ale } \\
\text { částečně uznán } \\
\text { jako samostatný } \\
\text { aktér (čínský } \\
\text { návrh na } \\
\text { tchajwanské } \\
\text { zapojení do } \\
\text { Asijské } \\
\text { infrastrukturní } \\
\text { investiční banky) }\end{array}$ & $\begin{array}{l}\text { Nárůst obchodní } \\
\text { výměny, } \\
\text { Tchaj-wan mezi } \\
\text { deseti nejvýz- } \\
\text { namnějšími } \\
\text { obchodními } \\
\text { partnery Číny }\end{array}$ & - \\
\hline & \multicolumn{5}{|c|}{ Čína jej považuje za svou integrální součást } \\
\hline
\end{tabular}

Zdroj: autorka

S Brunejí Čína v roce 2013 uzavřela společné prohlášení, ve kterém se strany zavazují k prohloubení vzájemných vztahů a k mírovému vyřešení sporů v Jihočínském moři (Embassy of The People's Republic of China 2013). ${ }^{12}$ Vztahy Filipín a Číny jsou narušeny vzájemnou nedůvěrou kvůli teritoriálním nárokům v Jihočín-

\footnotetext{
${ }^{11}$ Se všemi státy jsou navázány diplomatické vztahy (vyjma Tchaj-wanu).

${ }^{12}$ Hlavní myšlenkou této dohody je spolupráce mezi čínskou a brunejskou petrochemickou společností.
} 
ském moři. Na žádost Filipín byla zahájena arbitráž vưči Číně, jejíž rozsudek pro Filipíny sice zazněl pozitivně - čínské nároky nejsou podle Mezinárodního soudního dvora v Haagu dle mezinárodních norem, avšak Č́na rozhodnutí soudu odmítla (The Guardian 2016).

Složitější je uchopit čínsko-tchajwanské vztahy. Tchaj-wan se snaží získat plnou vnější suverenitu, přičemž Čína jej považuje za svou integrální součást. Ve vojenské oblasti proto nedochází k žádné spolupráci, ba naopak mezi nimi existuje značné bezpečnostní napětí (např. Čína má v Tchaj-wanské úžině rozmístěné vojenské síly). Potenciál však existuje v ekonomickém sektoru. Narůstá vzájemná ekonomická výměna (Tchaj-wan je v desítce nejvýznamnějších čínských obchodních partnerů) a Čína by navíc podpořila tchajwanskou účast v Asijské infrastrukturní investiční rozvojové bance pod „odpovídajícím jménem“ (Albert 2018). Na druhou stranu ale v roce 2014 proběhly na Tchaj-wanu protesty proti obchodní dohodě s Čínou (Cross-Strait Service Trade Agreement), která by podle protestujících měla učinit Tchaj-wan na Číně ekonomicky závislejším (BBC 2014).

\subsection{Politika nepŘíméHo VyVAŽování Číny}

Vzhledem k rostoucí moci Číny dochází k narušení statu quo v oblasti, kde doposud byly dominantními hráči USA a Japonsko. Na to USA začaly reagovat zejména v období administrativy prezidenta Baracka Obamy, kdy postupně dochází k obratu pozornosti z Atlantiku na Pacifik. To definuje Hillary Clinton (2011: passim) v článku „America’s Pacific Century pro Foreign Policy“. Základním východiskem bylo, že se jedná o rychle ekonomicky rostoucí oblast. Jedním ze způsobů, jak těžit z jejích ekonomických výhod byla i navrhovaná dohoda TPP, která podle prezidenta Baracka Obamy měla USA umožnit utvářet pravidla obchodu ve 21. století a nedopustit, aby byla utvářena zeměmi, jakou je právě Čína (Ford 2017). Dohoda TPP ale nebyla úspěšná, a USA navíc odmítly i čínské pozvání do Asijské infrastrukturní investiční banky, čímž se pozice USA v regionu oslabila. Kromě toho došlo i k zintenzivnění vojenského angažmá, na nějž Čína odpověděla navýšením aktivit (Ford 2017). Zaměření se na Asii-Pacifik podle některých autorů mimo jiné zapříčinilo odvrat pozornosti USA od jiných oblastí světa, jež tradičně spadaly do zájmu USA. ${ }^{13}$ Tím je myšlen zejména Blízký východ a Evropa, kde došlo k rozvinutí nových krizí (zformování a posílení Islámského státu či krize na Ukrajině). Současný prezident Donald Trump ve své Národní bezpečnostní strategii z roku 2017 (The President of the United States 2017: 46) hovoří o pokračování spolupráce s Čínou, přičemž je ale kladen důraz na její aktivity v Jihočínském moři, jež ,[...] ohrožuji volný tok obchodu, suverenitu ostatních národů a podkopávají regionální stabilitu". V současné době jsou ale vzájemné vztahy determinovány „celními válkami“. V této části se zaměřím na aktivity USA v regionu a na reakce států ležících $\mathrm{v}$ této oblasti, resp. na to, jak se projevuje nepřímé vyvažování s USA (základní rysy jsou shrnuty v tabulce 4). Proč je oblast Jihočínského moře důležitá s ohledem na národní zájmy USA? Patrick M. Cronin (2016) hovoří o čtyřech základních důvodech. Prvním z nich je narůstající geostrategická konkurence v podobě rostoucí Č́ny v regionu, kde byly doposud dominantní mocí

\footnotetext{
${ }^{13}$ Nelze však hovořit o tom, že by od těchto oblastí byla pozornost odvrácena úplně.
} 
USA. USA prochází testem, zda budou schopny projektovat svou bojovou sílu, anebo zda budou omezovány růstem čínské vojenské moci. Dále v této oblasti dochází k překrývání norem, pravidel a standardů určujících chování a mezinárodní vztahy v Asii a Pacifiku, a v neposlední řadě je oblast ekonomickým epicentrem bohatým na zdroje a životně důležitým uzlem pro globální lodní dopravu. Podle Cronina (2016) by měly USA k udržení své pozice v regionu využít všech svých kapacit od soft power po hard power ve snaze vypořádat se s výše zmíněnými hrozbami a problémy, ovšem nečelit každé hrozbě zvlášte, nýbrž je řešit jako celek.

USA se v regionu snaží prosazovat v různých oblastech, nicméně nejvýrazněji tak činí v sektoru vojenském, byt̉ deklarují, že je pro ně mnohem důležitější prosazování demokratických hodnot a lidských práv. Jejich strategii pro tento region označila Hillary Clinton (2011: 58) za tzv. předsunutou diplomacii (forwarddeployed diplomacy), jež spočívá ve využívání široké škály diplomatických prostředků - posilování bilaterálních bezpečnostních aliancí, prohlubování spolupráce s rozvíjejícími se mocnostmi (včetně Číny), zapojování se do regionálních multilaterálních institucí, rozšiřování obchodu a investic, upevňování vojenské přítomnosti, podpora demokracie a lidských práv. Hillary Clinton (2011: 63) ve výše zmíněném článku uvádí př́́klad Vietnamu, u něhož USA jako podmínku pro budování strategického partnerství vyžadují, aby Vietnam podporoval lidská práva. Nicméně v tomtéž článku Clinton (2011: 63) připomíná, že je nutné navýšit vojenskou prrítomnost USA v regionu, a to z důvodu, že „[...] bude možné snáze participovat na humanitárních misích a snáze podnikat společná cvičení se spojenci $v$ regionu, ale také bude možné efektivněji čelit hrozbám".

Státy jihovýchodní Asie mohou participovat na řadě aktivit USA, které by mohly využít k nepřímému vyvažování Číny. USA na počátku prvního období Obamovy administrativy spoléhaly zejména na kooperaci v environmentálním sektoru, ${ }^{14}$ protože panovalo přesvědčení, že spolupráce $\mathrm{v}$ boji proti klimatickým hrozbám minimalizuje geopolitické soupeření mezi zeměmi oblasti Jihočínského moře, nebot panoval předpoklad, že kdyby Čína nejevila zájem o prosazování norem na čelení klimatickým změnám, narušilo by to její mezinárodní image (Green 2016). Tato strategie se však neukázala jako nejúspěšnější. Jihovýchodoasijské státy se cítí být čínskými teritoriálními aktivitami v Jihočínském moři ohrožovány, ${ }^{15}$ je proto pochopitelné, že upřednostňují spolupráci s USA zejména v oblasti posílení bezpečnosti a obrany. Jak si ukážeme na př́ikladech níže, navazování vojenské spolupráce nad ostatními formami převládá. Než se pustíme do rozebírání jednotlivých sektorů, je záhodno uvést, že státy regionu jsou děleny na tradiční spojence a jejich nové partnery. Za tradiční spojence jsou pokládány Filipíny a Thajsko. Nová partnerství jsou navazována s Malajsií, Vietnamem ${ }^{16}$ a Brunejí (Clinton

\footnotetext{
${ }^{14}$ Jde např. o Lower Mekong Initiative na podporu vzdělávání, zdraví a životního prostředí v Kambodži, Laosu, Thajsku a Vietnamu, Pacific Islands Forum na podporu čelení výzvám klimatických změn, nadměrného rybolovu a svobody moří (Clinton 2011: 62).

${ }^{15}$ Jak již bylo zmiňováno výše - Čína zpevňuje některé ostrovy, buduje na nich základny a snaží se v oblasti Jihočínského moře o hegemonii.

${ }^{16}$ Poměrně významným počinem bylo kotvení americké letadlové lodi Carl Vinson ve vietnamském přístavu Danang v únoru 2018. Stalo se tak poprvé od roku 1975, kdy došlo ke stažení amerických vojsk z Vietnamu (Beech 2018).
} 
2011: 59) a rozvíjejí se postupně - s každým novým partnerem se vztahy prohlubují různým tempem.

Vojenský sektor. Pro vojenskou spolupráci mezi USA a jejich spojenci v Jihovýchodní Asii je charakteristické pořádání společných vojenských cvičení. Kromě nich je pro státy regionu navazování vztahů s USA výhodné i v tom ohledu, že se Washington zasazuje o dodržování svobody plavby. ${ }^{17}$ Společná vojenská cvičení a obrana principu svobodné plavby jsou podnikány ozbrojenými složkami USA v Pacifiku (U. S. Pacific Command společně s U. S. Navy, U. S. Airforce a U. S. Coast Guard) (U. S. Department of Defense 2015: 23). Úroveň a velikost společných vojenských cvičení, stejně tak jako jejich četnost, se postupně navyšuje. Vojenská spolupráce zahrnuje také nákupy zbraní od USA - v tomto př́ípadě zmiňme zejména Tchaj-wan (v reakci na rozmistování čínských sil v Tchaj-wanské úžině) (Albert 2018).

Nejrozsáhlejší program společných vojenských cvičení mají USA s Filipínami. Dle ministerstva obrany USA (U. S. Department of Defense 2015: 24) se např. v roce 2015 konalo na 400 společných cvičení různých rozměrů, z nichž se mezi největší řadí operace Balikatan, na níž kromě Filipínců a Američanů participují i jednotky Austrálie a Japonska (jako pozorovatel). Cílem cvičení s Filipínami je zajistit, aby Filipíny dosáhly alespoň minimální efektivní obrany. Od roku 1999 pak USA začínají podnikat společná vojenská cvičení s Vietnamem (U. S. Department of Defense 2015: 25), přičemž od roku 2015 dochází k jejich rychlému navyšování a poprvé se konala i společná vícedenní cvičení. Společná vojenská cvičení mají USA od roku 2015 i s Malajsií (poprvé spolu malajsijské a americké jednotky spolupracovaly už v roce 2014 ve východním Sabahu) a s Indonésií (U. S. Department of Defense 2015: 24). Největším společným cvičením nejen v regionu, ale i na světě, je RIMPAC. Jedná se o námořní cvičení, jehož cílem je vzájemně pochopit vojenské námořní taktiky, jež státy využívají k budování důvěry a vzájemnému porozumění, a předejít tak konfliktům, které by mohly vzejít právě ze vzájemného nepochopení taktik prováděných na moři. V roce 2014 se jej mimo jiné poprvé účastnila Čína, avšak pouze s omezeným přístupem. V roce 2016 Čína participovala podruhé (U. S. Department of Defense 2015: 25; Ministry of National Defence. The People's Republic of China 2016).

Ekonomický sektor. Jednou ze šancí, jak bylo možné vyvážit Čínu a posílit postavení USA v regionu, byla dohoda o volném obchodu TPP. Tu podepsalo na dvanáct zemí tichomořské oblasti, avšak žádná z nich ji neratifikovala. V současné době byla prezidentem USA Donaldem Trumpem definitivně odmítnuta. TPP měla utvořit zónu volného obchodu, která by se postupně měla transformovat na společný trh. Ačkoliv má TPP řadu kritiků, nelze upřít, že by se tak utvořila protiváha Číně - TPP by zahrnovala oblast, jež produkuje zhruba $40 \%$ světové ekonomické produkce (BBC 2017).

Politický sektor. Asi nejzřetelnějším počinem nepřímého vyvažování s USA v politickém sektoru je spolupráce s USA v oblasti řešení teritoriálních sporů v Jihočínském moři. USA se zasazují o mírové vyřešení sporů a o zajištění svobody

\footnotetext{
${ }^{17}$ Avšak svoboda plavby nemusí být vždy výhodná pro všechny strany. Např. Vietnam vyžaduje před proplutím válečných lodí jeho teritoriálními vodami předchozí oznámení, jež musí být zpětně potvrzeno, což neodpovídá zásadám UNCLOS (U. S. Department of Defense 2015: 7, 24).
} 
moří. Jak uvedla Hillary Clinton (dle Cronin 2016) na setkání ministrů zahraničních věcí zemí ASEAN v Hanoji v červenci 2010: „Spojené státy maji národní zájem ve svobodě plavby, otevřeném př́stupu $k$ asijskému námořnímu zvykovému právu a respektu $k$ mezinárodnímu právu v Jihočinském moři."

K mírovému vyřešení teritoriálních sporů v Jihočínském moři by mělo napomoci prosazení Deklarace o chování stran v Jihočínském moři (Declaration on the Conduct of Parties in the South China Sea), ale také blízké přijetí Kodexu chování (Code of Conduct), který má obsahovat společně přijatá pravidla proplutí s cílem zmenšit napětí mezi nárokujícími státy (U. S. Department of Defense 2015: 6).

Tabulka 4: Nepřímé vyvažování s USA

\begin{tabular}{|c|c|c|c|c|c|}
\hline & \multicolumn{2}{|c|}{ Vojenský } & \multicolumn{2}{|c|}{ Politický } & Ekonomický \\
\hline Vietnam & $\begin{array}{l}\text { Společná vojenská } \\
\text { cvičení }\end{array}$ & \multirow{4}{*}{ RIMPAC } & $\begin{array}{l}\text { Navázány } \\
\text { diplomatické } \\
\text { styky }\end{array}$ & \multirow{5}{*}{$\begin{array}{l}\text { Snaha prosadit } \\
\text { řešení mírových } \\
\text { sporů na úrovni, } \\
\text { snaha prosazovat } \\
\text { svobodu plavby }\end{array}$} & \multirow{4}{*}{$\begin{array}{l}\text { Potenciál TPP, } \\
\text { obchodní } \\
\text { výměna }\end{array}$} \\
\hline Malajsie & $\begin{array}{l}\text { Společná vojenská } \\
\text { cvičení od roku } \\
2015\end{array}$ & & $\begin{array}{l}\text { Navázány } \\
\text { diplomatické } \\
\text { styky }\end{array}$ & & \\
\hline Brunej & $\begin{array}{l}\text { Společná vojenská } \\
\text { cvičení }\end{array}$ & & $\begin{array}{l}\text { Navázány } \\
\text { diplomatické } \\
\text { styky }\end{array}$ & & \\
\hline Filipíny & $\begin{array}{l}\text { Strategické } \\
\text { partnerství, } \\
\text { vojenská aliance } \\
\text { s USA, poskytnutí } \\
\text { vojenské základny, } \\
\text { společná vojenská } \\
\text { cvičení }\end{array}$ & & $\begin{array}{l}\text { Podpora } \\
\text { arbitráže }\end{array}$ & & \\
\hline Tchaj-wan & $\begin{array}{l}\text { Nákup zbraní od } \\
\text { USA }\end{array}$ & - & $\begin{array}{l}\text { Rétorická } \\
\text { podpora } \\
\text { nároků na } \\
\text { teritoriální } \\
\text { vody a } \\
\text { přilehlou } \\
\text { zónu, tradice } \\
\text { z období } \\
\text { studené války }\end{array}$ & & $\begin{array}{l}\text { Devátý } \\
\text { nejvýznamnější } \\
\text { obchodní } \\
\text { partner (U. S. } \\
\text { Department of } \\
\text { State 2017) }\end{array}$ \\
\hline
\end{tabular}

Zdroj: autorka

\subsection{VtahovÁNí daLších aKTÉRŮ}

Poslední charakteristikou strategie zajištování je vtahování dalších aktérů. Všechny státy se snaží navazovat vztahy se státy i mimo region, typicky s Japonskem, Austrálií či Novým Zélandem. Na následujících řádcích představíme ty aktivity, na kterých státy regionu participují společně a kdy je vtahování dalších států rozhodnutím všech (tj. kdy se jedná o vtahování jen na multilaterální úrovni, nikoliv na bilaterální).

Vojenský sektor. Ve vojenském sektoru se zaměříme na RIMPAC. Vojenské cvičení, o němž byla řeč již výše, je jedním z příkladi̊, jak vtahovat další aktéry do řešení teritoriálních sporů. V roce 2016 se ho účastnilo 26 zemí, z nichž ně- 
které nepatří k tichomořským státům, vyberme některé: USA, Austrálie, Kanada, Dánsko, Francie, Indie, Indonésie, Japonsko, Malajsie, Nový Zéland, Čína, Singapur, Filipíny, Thajsko, Tongo či Spojené království (America’s Navy 2016). Díky společným vojenským cvičení se naskýtá možnost, jak snížit riziko, že se země budou spojovat do vojenských paktů a aliancí. Je tedy patrné, že ačkoliv se jedná o vojenské cvičení zaměřené na státy Pacifiku, účastní se jej i státy ležící mimo tuto oblast. Tím jsou tyto státy vtahovány do řešení teritoriálních sporů, minimálně v tom ohledu, že je pro ně výhodné, aby námořní cesty v Jihočínském moři byly volně proplutelné bez bezpečnostních rizik.

Ekonomický sektor. V ekonomickém sektoru docházelo ke dvěma protichůdným projektům, které vznikaly v reakci na sebe - TPP a RCEP. TPP vzešlo z iniciativy USA a mělo do něj být zapojeno 12 zemí: USA, Austrálie, Brunej, Kanada, Chile, Japonsko, Malajsie, Mexiko, Nový Zéland, Peru a Singapur. Naproti tomu RCEP je početnější: země ASEAN, ${ }^{18}$ Austrálie, Čína, Indie, Japonsko, Jižní Korea a Nový Zéland. Všimněme si, že hlavním rozdílem je účast vždy jen jednoho ze států - Číny, nebo USA. Ani na jednom z projektů neparticipují oba státy zároveň. Nicméně TPP byla odmítnuta současným prezidentem USA Donaldem Trumpem - otázkou tedy je, zda má TPP bez USA nějaký potenciál. V ekonomickém sektoru je pak důležitým faktorem i APEC, na němž se sice nepodílí Vietnam, ale na druhou stranu je jeho součástí jak Čína, tak Tchaj-wan.

Politický sektor. V tomto sektoru dochází k politickým aktivitám na půdě organizace ASEAN. Jednání ohledně sporů v Jihočínském moři se účastní jak Čína, tak i USA. Nicméně je nutno říci, že i přes snahy ASEAN vyřešit spory mírovou cestou se to organizaci příliš nedaří a vzhledem k tzv. ASEAN way ${ }^{19}$ není organizace v této otázce př́liš akceschopná. Nelze ji však upřít její funkci diskuzní platformy, jež se snaží do svých činností vtáhnout další aktéry i mimo region Jihovýchodní Asie (např. ASEAN+3).

Tabulka 5: Vtahování dalších aktérů

\begin{tabular}{|c|l|c|}
\hline Vojenský & \multicolumn{1}{|c|}{ Politický } & Ekonomický \\
\hline \hline RIMPAC & $\begin{array}{l}\text { ASEAN a vtahování aktérů mimo region } \\
\text { (např. ASEAN+3) }\end{array}$ & TPP, RCEP, APEC \\
\hline
\end{tabular}

Zdroj: autorka

\section{ZÁVĚR}

Teritoriální spory v Jihočínském moři patří k determinantům vztahů v oblasti Jihočínského moře, zejména pak v souvislosti s čínským růstem a jejím deklarováním jejích zájmů v Jihočínském moři v její Bílé knize obrany z roku 2015. Aby si státy upevnily své nároky na území v Jihočínském moři, snaží se ostrovy „obydlovat“.

\footnotetext{
${ }^{18}$ Brunej, Kambodža, Indonésie, Laos, Malajsie, Barma/Myanmar, Filipíny, Singapur, Thajsko a Vietnam

${ }^{19}$ ASEAN přijímá rozhodnutí na základě konsenzu - nemohou-li státy konsenzus nalézt, řešení problému se raději odloží, než aby mezi státy vznikl nějaký vážnější rozpor.
} 
Menší státy se čínskými teritoriálními aktivitami cítí být ohroženy a hledají cesty, jak co nejvíce rozptýlit možná rizika. I nejmenší akce USA a Číny mohou být těmito státy chápány jako změna kurzu v dosavadním statu quo.

Podle strategie zajištování by státy měly s Čínou více spolupracovat či se s ní interagovat, aby ji socializovaly v rámci mezinárodního systému, dále by Čínu měly nepřímo vyvažovat s USA a v neposlední řadě by mělo docházet ke vtahování dalších aktérů. Je však strategie zajištování východiskem pro malé státy Jihočínského moře?

V případě interakce s Čínou s cílem socializovat ji v rámci mezinárodního systému je otázkou, zda skutečně státy takto jednají, aby ji socializovaly. Podle čínské strategie Going global (Eichler 2013: 232) je čínským záměrem dodržovat pravidla mezinárodního systému a řešit problémy multilaterálně. Je skutečně důvodem, proč státy přistupují k iniciativám, jako je námořní hedvábná stezka, socializovat Čínu v rámci mezinárodního systému? Čína sama chápe, že je pro ni výhodné přistoupit na multilaterální pravidla a udržovat mír $^{20}$ (aby si zachovala hospodářský růst). Na druhou stranu menší státy v okolí Jihočínského moře nepatří k silným ekonomikám, a proto je pro ně výhodné s Čínou spolupracovat i z ekonomických důvodů a ne jen kvůli jejímu socializování se a k tomu, aby státy této oblasti snížily riziko střetů způsobených teritoriálními nároky v Jihočínském moři. Jediným státem, se kterým Čína navázala strategické partnerství, je Malajsie. Ta zastává pročínský postoj a snaží se přehlížet čínské snahy o získání teritoria v Jihočínském moři. Společně s Brunejí jsou to jediné státy, o kterých lze říci, že jsou Č́ně více nakloněné a že naplňují podmínku strategie zajištování hovořící o zahraniční politice angažovanosti s Čínou.

Co se týče nepřímého vyvažování moci Číny a USA, je dominantním sektorem vyvažování moci sektor vojenský. Státy oblasti Jihočínského moře participují na společných vojenských cvičeních. USA mají v oblasti jediného strategického spojence, kterým jsou Filipíny, ty jsou však naproti tomu významnou investiční zemí Číny. Opět zde vyvstává otázka, zda státy Jihočínského moře s USA skutečně spolupracují s cílem vyvažování čínského mocenského vzrůstu, či zda tak činí pouze z důvodu, že je pro ně výhodné mít nakloněnu nejen Čínu, ale i další významnou mocnost regionu. Př́kladem mohou být Filipíny, které mají s USA navázáno strategické partnerství, ale na druhou stranu jsou i významnou investiční zemí Číny a v současné době se nebrání ani bilaterálním vojenským cvičení s Čínou.

V rámci vtahování dalších aktérů do řešení sporů v Jihočínském moři, byla pozornost zaměřena na ASEAN, RIMPAC, TPP a RCEP, na nichž participují i státy mimo oblast Jihočínského moře. Jistě tyto multilaterální aktivity přispívají k řešení sporů v Jihočínském moři a znesnadňují budování čínské hegemonie, nicméně spolupracují státy Jihočínského moře se státy vně regionu pouze z důvodu, aby čínské hegemonii zabránily?

Strategie zajištování se jeví jako východisko pro vyrovnání se s růstem Číny v regionu Jihočínského moře a jak zmiňují autoři s ní pracující (viz výše), není strategie zajištování př́liš rozvinutým konceptem. V oblasti Jihočínského moře jsou naplňovány charakteristiky této strategie, byt některé státy se ve strategii jeví jako aktivnější (např. Filipíny), jiné zase pasivnější (např. Brunej či Malajsie mající silný

\footnotetext{
${ }^{20}$ Chce Č́na nastolit nový mezinárodní systém anebo být vítězem toho současného?
} 
pročínský postoj, ale s USA nemají žádné výjimečné vztahy - jedná se zejména o společná vojenská cvičení, která jsou však typická pro všechny státy Jihočínského moře). Ačkoliv jsou tedy charakteristiky strategie zajištování naplňovány a je možné tuto strategii na politiky v oblasti Jihočínského moře aplikovat, je zde ještě prostor pro její rozpracování - to, že státy v oblasti nevytvářejí vojenské aliance či přímo neustupují, je možné považovat pouze za projev současných podmínek globalizovaného světa, kde je pro státy prostě výhodné, aby spolupracovaly s dalšími aktéry. Navíc je poměrně diskutabilní bod, ve kterém se hovoří o socializování Číny do mezinárodního systému (viz výše), protože Čína se chce sama podílet na budování multilaterálního světa, státy oblasti Jihočínského moře ji do něj socializovat nemusí.

\section{BIBLIOGRAFIE}

ABS CBN. 2017. „Duterte open to joint military exercises with China. “ [online] abscbn.com, 5. 1. 2017 [cit. 4. 2. 2017]. Dostupné z: http://news.abs-cbn.com/news/05/01/ 17/duterte-open-to-joint-military-exercises-with-china.

Albert, E. 2018. „China-Taiwan Relations." [online] Council on Foreign Relations, 15. 6. 2018 [cit. 20. 6. 2018]. Dostupné z: https://www.cfr.org/backgrounder/china-taiwanrelations.

America's Navy. 2016. „Commander, Naval Surface Force, U. S. Pacific Fleet." [online] America's Navy. U. S. Pacific Fleet, 30. 6. 2016 [cit. 9. 3. 2017]. Dostupné z: http://www.public.navy.mil/surfor/Pages/RIMPAC-2016.aspx\#.WzCaXaczZPZ.

AMTI. 2017. „Updated: China's Big Three Near Completion." [online] Asia Maritime Transparency Initiative, 29. 6. 2017 [cit. 21. 7. 2017]. Dostupné z: https://amti.csis.org/ chinas-big-three-near-completion/.

ASEAN. 2016a. „Regional Comprehensive Economic Partnership (RCEP).“ [online] $A S E A N$, 3. 10. 2016 [cit. 19. 5. 2017]. Dostupné z: http://asean.org/?static_post=rcepregional-comprehensive-economic-partnership.

ASEAN. 2016b. "Treaty of Amity and Cooperation in Southeast Asia Indonesia, 24 February 1976." [online] $A S E A N$, 27. 1. 2016 [cit. 19. 5. 2017]. Dostupné z: http: //asean.org/treaty-amity-cooperation-southeast-asia-indonesia-24-february-1976/.

BBC. 2014. „Mass protest held in Taiwan against China trade deal." [online] bbc.com, 30. 4. 2014 [cit. 20. 6. 2018]. Dostupné z: https://www.bbc.com/news/world-asia-26809066.

BBC. 2016. "Why is the South China Sea contentious?" [online] bbc.com, 12. 6. 2016 [cit. 28. 1. 2017]. Dostupné z: http://www.bbc.com/news/world-asia-pacific-13748349.

BBC. 2017. „TPP: What is it and why does it matter?" [online] bbc.com, 23. 1. 2017 [cit. 29. 1. 2017]. Dostupné z: http://www.bbc.com/news/business- 32498715.

Beech, H. 2018. „U. S. Aircraft Carrier Arrives in Vietnam, With a Message for China.“ [online] The New York Times, 4. 3. 2018 [cit. 20. 8. 2016]. Dostupné z: https://www. nytimes.com/2018/03/04/world/asia/carl-vinson-vietnam.html.

Brooks, K. B. 2016. „What Future for the Asia Pivot Under Trump?" [online] Council on Foreign Relations, 14. 12. 2016 [cit. 20. 6. 2018]. Dostupné z: https://www.cfr.org/ expert-roundup/what-future-asia-pivot-under-trump.

CIA. 2018. „East and Southeast Asia: Paracel Islands.“ [online] Central Intelligence Agency, 29. 3. 2018 [cit. 14. 6. 2018]. Dostupné z: https://www.cia.gov/library/ publications/the-world-factbook/geos/pf.html. 
CIL NUS. 2000. „Agreement between the People's Republic of China and Rhe Socialist Republic of Viet Nam on the Delimitation of the territorial seas, exclusive economic zones and the continental shelves of the two countries in Beibu Gulf/Bac Bo Gulf. " [online] Centre fot International Law, 25. 12. 2000 [cit. 13. 5. 2018]. Dostrupné z: cil.nus.edu.sg/wp-content/ uploads/formidable/18/2000-Agmt-between-China-and-Vietnam-on-Delimitation-ofTerritorial-Seas.pdf.

Clinton, H. 2011. „America's Pacific Century.“ Foreign Policy 189: 68-76.

CNOOC. 2013. „CNOOC and Petroleum Brunei Sign Agreement on Setting up Joint Venture." [online] cnooc.com.cn, 14. 10. 2013 [cit. 20. 6. 2018]. Dostupné z: http://www. cnooc.com.cn/data/html/news/2013-10-14/english/346339.html.

Cronin, P. M. 2016. „Power and Order in South China Sea." [online] Center for a New American Security, 10. 11. 2016 [cit. 24. 2. 2017]. Dostupné z: https://www.cnas.org/ publications/reports/power-and-order-in-the-south-china-sea.

Devadson, E. S. 2015 „Framing China-Malaysia Trade Relations Beyond ASEAN: Factoring The Regional Comprehensive Economic Partnership." The Journal of Economic Areas 49 (2): 39-56, http://dx.doi.org/10.2139/ssrn.2438478.

Do, Q. A. 2017. „Significance of Sino-Vietnam Relations.“ [online] moderndiplomacy.eu, 24. 12. 2017 [cit. 20. 6. 2018]. Dostupné z: https://moderndiplomacy.eu/2017/12/24/ significance-sino-vietnam-relations/.

Eichler, J. 2013. Bezpečnostní a strategická kultura mezinárodních organizací a ČLR. Praha: Oeconomica.

Embassy of The People's Republic of China. 2013. „China and Brunei Decide to Strengthen Maritime Cooperation to Promote Joint Development." [online] Embassy of The People's Republic of China, 11. 10. 2013 [cit. 14. 5. 2017]. Dostupné z: http://bn. chineseembassy.org/eng/zwgx/t1092901.htm.

Ford, J. 2017. „The Pivot to Asia Was Obama's Biggest Mistake." [online] TheDiplomat.com, 21. 1. 2017 [cit. 20. 6. 2017]. Dostupné z: https://thediplomat.com/2017/01/ the-pivot-to-asia-was-obamas-biggest-mistake/.

Freiner, N. L. 2018. „What China's RIMPAC Exclusion Means for US Allies.“ [online] TheDiplomat.com, 26. 5. 2018 [cit. 20. 6. 2018]. Dostupné z: https://thediplomat.com/ 2018/05/what-chinas-rimpac-exclusion-means-for-us-allies/.

Gao, Z., B. J. Bing. 2013. „The Nine-Dash Line in the South China Sea: History, Status, and Implications." The American Journal of International Law 107 (1): 98-124, https://doi.org/10.5305/amerjintelaw.107.1.0098.

Goh, E. 2005. Meeting the China Challenge: The U. S. in Southeast Asian Regional Security Strategies. East-West Center Washington: Washington.

Green, M. 2016. „The Legacy of Obama's "Pivot" to Asia." [online] Foreign Policy, 3. 9. 2016 [cit. 13. 2. 2017]. Dostupné z: http://foreignpolicy.com/2016/09/03/ the-legacy-of-obamas-pivot-to-asia/.

Hlaváček, P. 2016. „Strategie zajištování států Jihovýchodní Asie.“ Mezinárodní vztahy 51 (4): 53-72.

Hunt, K. 2016. „South China Sea: Court Rules In Favor of Philippines over China." [online] cnn.com, 12. 7. 2016 [cit. 13. 2. 2017]. Dostupné z: http://edition.cnn.com/2016/07/ 12/asia/china-philippines-south-china-sea/index.html.

Kang, D. C. 2003. „Getting Asia Wrong: The Need for New Analytical Frameworks.“ International Security 27 (4): 57-85, https://doi.org/10.1162/016228803321951090.

Kuik, Ch. 2016. „How Do Weaker States Hedge? Unpacking ASEAN states' alignment behavior towards China." Journal of Contemporary China 100 (25): 500-514, https://doi.org/10.1080/10670564.2015.1132714. 
Lu, J. 2016. „The $21^{\text {st }}$ Century Maritime Silk Road and China-ASEAN Industry Cooperation." International Journal of China Studies 7 (3): 375-389.

Ministry of Foreign Affairs Republic of China (Taiwan). 2016. „International scholars visit Taiping Island." [online] Ministry of Foreign Affairs Republic of China (Taiwan), 15. 4. 2016 [cit. 20. 6. 2018]. Dostupné z: https://www.mofa.gov.tw/en/News_Content.aspx? $\mathrm{n}=1 \mathrm{EADDCFD} 4 \mathrm{C} 6 \mathrm{EC} 567 \& \mathrm{~s}=0 \mathrm{CE} 8 \mathrm{FC} 86 \mathrm{CAEED} 693$.

Ministry of National Defence. The People's Republic of China. 2015. „China's Military Strategy. " [online] Ministry of National Defence. The People's Republic of China, 26. 5. 2015 [1. 3. 2017]. Dostupné z: http://eng.mod.gov.cn/Press/2015-05/26/content_ 4586805.htm.

Ministry of National Defence. The People's Republic of China. 2016. "Chinese fleet arrives in Hawaii for RIMPAC 2016 drill." [online] Ministry of National Defence. The People's Republic of China, 30. 6. 2016 [cit. 15. 3. 2017]. Dostupné z: http://eng.mod.gov.cn/ DefenseNews/2016-06/30/content_4685135.htm.

Ministry of National Defence. The People's Republic of China. n. d. „Military Exercises.“ [online] Ministry of National Defence. The People's Republic of China, nedatováno [cit. 16. 3. 2017]. Dostupné z: http://eng.mod.gov.cn/MilitaryExercises/index.htm.

Myers, S. L. 2018: „Island or Rock? Taiwan Defends Its Claim in South China Sea." [online] The New York Times, 20. 5. 2018 [cit. 20. 6. 2018]. Dostupné z: https://www. nytimes.com/2018/05/20/world/asia/china-taiwan-island-south-sea.html.

Parameswaran, P. 2014. „China Begin First Joint Military Excersise." [online] TheDiplomat.com, 24. 12. 2014 [cit. 13. 2. 2017]. Dostupné z: http://thediplomat.com/2014/12/ malaysia-china-begin-first-joint-military-exercise.

Parameswaran, P. 2017. „China: New White Paper, Old Asia Conundrum." [online] TheDiplomat.com, 4. 2. 2017 [cit. 20. 6. 2018]. Dostupné z: https://thediplomat.com/ 2017/02/china-new-white-paper-old-asia-conundrum/.

SQW China Group. 2014. „Brunei-Guangxi sign on for economic corridor." [online] SQW China Group, 17. 9. 2014 [cit. 9. 1. 2017]. Dostupné z: http://sqwchinagroup.com/ brunei-guangxi-sign-on-for-economic-corridor/.

Strašáková, M. 2017. „Sino-Vietnamese Relations: Accommodating the Dragon?“ Příspěvek přednesený na konferenci ISA International Conference 201\%: The Pacific Century? Hongkong, 15.-18. 6. 2017. Dostupné z: http://web.isanet.org/Web/Conferences/ HKU2017-s/Archive/503efcf1-e485-4559-83ab-836df4459b1f.pdf.

Tessman, B., W. Wolfe. 2011. „Great Power and Strategic Hedging: The Case of Chinese Energy Security Strategy." International Studies Review 13 (2): 214-240, https: //doi.org/10.1111/j.1468-2486.2011.01022.x.

The Guardian. 2011. „China's first aircraft carrier launches with pride amid regional tensions." [online] TheGuardian.com, 10. 8. 2011 [cit. 20. 6. 2018]. Dostupné z: https: //www.theguardian.com/world/2011/aug/10/china-aircraft-carrier-launch.

The Guardian. 2016. „Beijing rejects tribunal's ruling in South China Sea case. “ TheGuardian.com, 12. 7. 2016 [cit. 15. 4. 2017]. Dostupné z: https://www.theguardian.com/ world/2016/jul/12/philippines-wins-south-china-sea-case-against-china.

The President of the United States. 2017. „National Security Strategy." [online] The President of the United States [cit. 20. 6. 2018]. Dostupné z: https://www.whitehouse. gov/wp-content/uploads/2017/12/NSS-Final-12-18-2017-0905.pdf.

U. S. Department of Defense. 2015. „US Maritime Security Strategy. " [online] U. S. Department of Defense, 14. 8. 2015 [cit. 7. 1. 2017]. Dostupné z: https://www.defense.gov/ Portals/1/Documents/pubs/NDAA\%20A-P_Maritime_SecuritY_Strategy-081420151300-FINALFORMAT.PDF. 
U. S. Department of State. 2017. „U. S. Relations With Taiwan. “ [online] U. S. Department of State, 13. 9. 2017 [cit. 3. 10. 2017]. Dostupné z: https://www.state.gov/r/pa/ei/ bgn/35855.htm.

UN. 1982 „United Nations Convention on the Law of the Sea." [online] United Nations [cit. 7. 1. 2017]. Dostupné z: http://www.un.org/depts/los/convention_agreements/texts/ unclos/unclos_e.pdf.

Vuving, A. L. 2016. „Who Occupies What in Spratlys." [online] TheDiplomat.com, 6. 5. 2016 [cit. 13. 2. 2017]. Dostupné z: http://thediplomat.com/2016/05/south-chinasea-who-claims-what-in-the-spratlys.

\section{SUMMARY}

At present, a shifting balance can be seen in the South China Sea that has attracted the attention of actors in the region and scholars of international relations. A growth in territorial demands has been evident primarily after the adoption of UNCLOS in connection with the definition of an exclusive economic zone. Nevertheless, the heightened activity of countries in the region in establishing their demands has been evident since 2015 when China issued a new defense white paper in which it declared its intentions in the South China Sea. China is one of the dominant actors in this area and sees a part of the South China Sea to be its territorial waters. This, however, interferes in the territorial waters of countries in the area that form a ring around the South China Sea. These states are thus looking for a path to ensure their position in the region. The USA, which has its own traditional interests in this region, also comes into play here.

In this paper, the author attempts to explain the relations between China, the USA, the South China Sea states, and selected international organizations/regimes in terms of a hedging strategy. A hedging strategy in this context is applied to the behavior of the South China Sea states in their attempt to confront China's growing power and also to benefit from the presence of the USA in the region. The paper's basic concept is that this hedging strategy offers an alternative perspective on the present situation in the region in comparison to classic theories of international relations. The goal of the paper is to present the ways in which the states of South East Asia use elements of hedging strategies in their politics, specifically in reaction to China's activity in this area. It studies how individual parts of this strategy are fulfilled in the foreign policy of selected South East Asian countries in military, economic, and geopolitical areas.

The hedging strategy seems to represent a starting point for balancing China's growth in the South China Sea region, but it is a concept that has yet to be elaborated. Elements of the strategy are fulfilled, although some states are more active players (e.g. the Philippines) and others more passive (e.g. Brunei). The hedging strategy consists of three elements - to engage with China with the goal of socializing it in the international system, to indirectly balance with the USA in order to ensure that China is not inclining toward isolation, and finally to draw in other influential actors to create stable regional order. Although it is the author's view that characteristics of the hedging strategy can be applied to policies in the South China Sea, the question of the suitability of this concept remains unanswered due to the lack of elaboration on the subject. 